\title{
Halal Tourism Promotion in Indonesia: An Analysis on Official Destination Websites
}

\author{
Muhammad Suradin* \\ Ministry of Tourism Republic of Indonesia, Jakarta, Indonesia
}

Abstract

Nowadays, Halal tourism has become a popular form of tourism which attracting many countries to capitalize on the Muslim market. However, because of the Islamic law, targeting this market segment may not be the same as targeting the mundane tourism segment. Hence, a cohort of studies suggests that the internet could be a solution to reach this specific tourism market. Furthermore, some studies also suggest that to influence Muslim tourism destination choice, tourism destination organizations should use Islamic Attributes of Destination in their promotion campaigns. This is also the case of Indonesia as the world's biggest Muslim country, which is trying to attract Muslim tourists visit. Nevertheless, the existing studies on halal tourism promotion in Indonesia are still scarce. Adopting the qualitative form of content analysis, this research tries to add to the scant studies on halal tourism destination promotion in Indonesia by examining the content in official websites of DMOs according to the Indonesia's national plan on Halal tourism.

Keywords: Halal Tourism, Islamic Attributes of Destination, Destination Management Organization, Websites.

\section{INTRODUCTION}

Indonesia is a homeland for 238.5 million people [1] makes it the world's fourth-most populated country as well as the world's largest Muslim country [2]. In addition, Indonesia's economy is recognized as the world's 10th largest economy in terms of purchasing power parity and members of the G20 [3]. Furthermore, tourism is considered as an important industry [4], an industry that plays a pivotal part and a vital contributor to Indonesia's national GDP and employment, as shown in Table 1.

In order to maintain the positive impact derived from tourism, the Ministry of Tourism of the Republic of Indonesia initiated the Indonesia Halal Tourism in 2012 and continued with hosting the $1^{\text {st }}$ IOC International Forum on Islamic Tourism in Jakarta in June, 2014 and launching the Minister of Tourism and Creative Economy Decree Number 2 in 2014, which specifically regulates Shari'a hotels in Indonesia $[5,6]$.

Furthermore, in the last several years Indonesia has been experiencing a consistent growth of international Muslim tourist arrivals, as illustrated in Figure 1. Indeed, there are several main generating markets for Indonesia including Saudi Arabia, the United Arab Emirates (from here refer as the UEA), Qatar, Kuwait, and Malaysia among others [7]. In addition, Indonesia

\footnotetext{
${ }^{*}$ Correspondence address: Muhammad Suradin Email: muh.suradin@gmail.com Address: Ministry of Tourism, Building Sapta Pesona-Ministry of Tourism, Medan Merdeka Barat No.17, Jakarta Pusat 10110.
}

is also considered one of the world's prominent destinations for Halal tourism according to the latest Global Muslim Travel Index (GMTI) report [8], as shown in Table 2.

Table 1. Indonesia Absolute Contribution in 2016

\begin{tabular}{|c|c|c|c|c|c|}
\hline \multicolumn{2}{|c|}{$\begin{array}{c}\text { Travel and } \\
\text { Tourism Total } \\
\text { Contribution to } \\
\text { GDP }\end{array}$} & \multirow{2}{*}{$\begin{array}{c}\begin{array}{c}2016 \\
\text { (US\$\$bn) }\end{array} \\
1001\end{array}$} & \multicolumn{2}{|c|}{$\begin{array}{l}\text { Travel and } \\
\text { Tourism Total } \\
\text { Contribution to } \\
\text { Employment }\end{array}$} & \multirow{2}{*}{$\begin{array}{r}2016 \\
\text { ('000 } \\
\text { jobs) } \\
69528\end{array}$} \\
\hline 2 & China & & 1 & China & \\
\hline 7 & India & 208.9 & 2 & India & 40343 \\
\hline 12 & Australia & 136.2 & 5 & Philippines & 7357.2 \\
\hline 15 & Thailand & 82.5 & 7 & Indonesia & 6708.6 \\
\hline 20 & Philippines & 60.1 & 9 & Thailand & 5739 \\
\hline 22 & Indonesia & 57.9 & & Vietnam & 4002.8 \\
\hline \multicolumn{2}{|c|}{ World Average } & 57.3 & \multicolumn{2}{|c|}{ SE Asia Average } & 3015.5 \\
\hline 27 & Malaysia & 40.4 & & Cambodia & 2252.3 \\
\hline 50 & Vietnam & 12.7 & \multicolumn{2}{|c|}{ World Average } & 2152.9 \\
\hline SE & ia Average & 30.1 & 24 & Malaysia & 1700.7 \\
\hline
\end{tabular}

In fact, Lombok-West Nusa Tenggara, won 2 awards in the World Halal Travel Summit 2015 [10]. Apart from this, the Ministry of Tourism of the Republic of Indonesia (from here referred as the MTRI), as the National Tourism Organization (from here referred as the NTO) has announced 10 regions as the main destination for Halal tourism [11], including Aceh, Central Java, East Java, Riau, Riau Archipelago, Jakarta, Yogyakarta, South Sulawesi, West Java, West Nusa Tenggara, and West Sumatra. Moreover, in 2016 the MTRI had launched a new website for promoting Halal tourism, namely, the Halaltourism.id, as shown in Figure 2. 


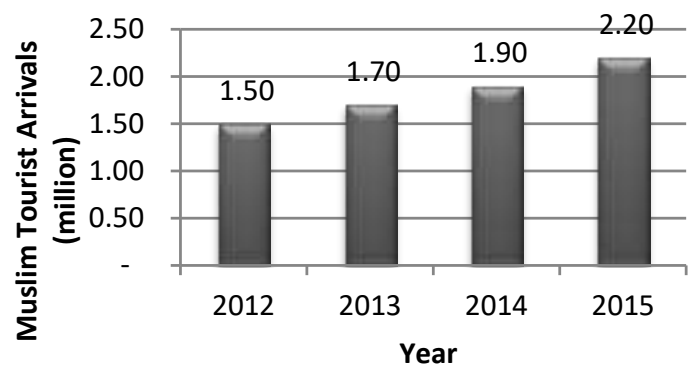

Figure 1. Indonesia International Muslim Tourist Arrival

Table 2. The OIC Main Destinations of GMTI

\begin{tabular}{cccc}
\hline & $\mathbf{2 0 1 6}$ & \multicolumn{2}{c}{$\mathbf{2 0 1 7}$} \\
\hline Rank & Destination & Rank & Destination \\
\hline 1 & Malaysia & 1 & Malaysia \\
2 & The UEA & 2 & The UEA \\
3 & Turkey & $\mathbf{3}$ & Indonesia \\
$\mathbf{4}$ & Indonesia & 4 & Turkey \\
5 & Qatar & 5 & Saudi Arabia \\
6 & Saudi Arabia & 6 & Qatar \\
7 & Oman & 7 & Morocco \\
\hline
\end{tabular}

Source: MasterCard and Crescent Rating [8]

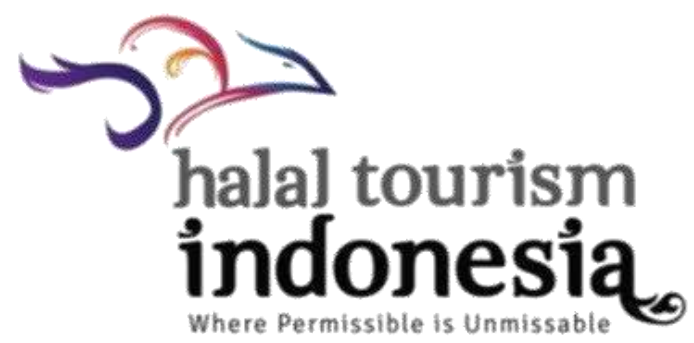

Figure 2. Indonesia Halal Tourism Brand

This new brand is part of Indonesia's national plan to be the World's Best Halal Tourism Destination with a target of 20 million international tourist arrivals in 2019 [7,12]. Nevertheless, according to the latest report from the Standing Committee for Economic and Commercial Cooperation (from here referred as the COMCEC), Indonesia is one of the countries that need to improve its competitiveness in digital marketing [13]. Additionally, the studies of Halal tourism promotion are still limited, especially in Indonesia, which only examines the website owned by the NTO. Therefore, this present research is essential to add to the scant studies on online Halal tourism promotion in Indonesia by examining official websites belonging to several DMOs whose listed destinations are part of the Indonesian national plan on Halal tourism.

\section{HALAL TOURISM}

The Halal concept is originally derived from the verb Halla in Arabic language, which literally means to be or become lawful, legal, licit, legitimate, permissible, permitted, allowable, allowed, admissible, un-prohibited, un-forbidden, to untie, unfasten, unbind, undo, unravel, loosen, unloosen, unfix, unwind, unscrew, untangle, disentangle, disengage, free - according to Islamic law or Shari'a law [14]. In addition, some scholars argue $[13,16]$ that the Islamic law or Shari'a law is developed from the Holy Qur'an; that is clearly noted mainly in the Surah 45 verses 18: Now We have set you [Muhammad PBUH] on a clear religious path (Shari'a), so follow it. Do not follow the desires of those who lack (true) knowledge [18] and the Sunnah. Particularly for this study, the author prefers to use the term Islamic law to describe the Shari'a law in order to help the readers understand the whole picture of Halal in Islam. Furthermore, the official sources of Islamic law, particularly for this paper, the focus is on the four official sources of the Islamic law based on Islamic Sunni, which is the sect with the largest population in the world $[16,18]$ including the Holy Qur'an, Sunnah, Ijma and ljtihad.

Despite the fact that the extent of these laws is enforced varies from country to country [19], Esposito argues that the Islamic law plays an important role to every Muslim all around the globe because of its comprehensive coverage [20]. Indeed, some studies confirm that Islamic law has myriad effects on Muslims' behavior and decision-making, ranging from religious ritual [20] to more common issues, for instance, Islamic banking [21], supply chain [22], Muslim-friendly hospitality [23], food [24], and travel and tourism [25].

In respect of the implementation of Islamic law in tourism, Sanad et al. [29] argue that there has been much controversy, if not dispute, especially among non-Muslims over the attitude of Islam to tourism, which mostly occurs because of the misunderstanding of the true nature of the religion and its Shari'a or Islamic law. Study on the role of Islam in the encounters of hosts and guest argue that tourism is historically an essential part of Islam and is encouraged by the Islamic law [26]. In fact, this study also mentioned several verses written in the Holy Qur'an that specifically encourage Muslims to visit another place outside their own in order to see the first-hand beauty and bounty of His creation; grasping the smallness of man reinforces the greatness of God, as well as increase personal knowledge, well-being and health [26]. Furthermore, according to some 
scholars $[27,28,29]$, there are several forms of religious travel that every Muslim is encouraged to do at least once during their lifetime as part of their obligation to worship God as well as the way to rejuvenate the value of Islam:

a. The Hajj or the pilgrimage from a Western perspective, has attracted millions of pious male as well as female Muslims from all around the world to visit the Kingdom of Saudi Arabia every year [28].

b. Umrah is referred to as the lesser pilgrimage or the minor Hajj [29]. On the other hand, based on the data from the Hajj Ministry of Saudi Arabia, approximately 400,000 Umrah visa were issued every month and projected to grow to 1.25 million per month after the Grand Mosque expansion project is finished in 2018 [30].

c. Ziyara. This term literally means a voluntary visitation to the shrine and tomb in various places, with the intention to pray and for remembrance of the dead person as well as the reflection of one's self of in the afterlife [27]. In addition, the study on ziyarat from the Islamic religious typology explained many Muslims also travel for this specific purpose to other well-known shrines and mausoleums in the Middle East and North Africa region (from here referred as the MENA region) and to non-Arab countries in several Asian regions [31].

d. Rihla. Al Rihla often refers by Muslims who travel to visit the shrine in Mecca, Medina and other places such as Jerusalem [32]. Furthermore, according to the El Moudden [33] study of Rihla from 1300 to $1800 \mathrm{CE}$, travel in the Muslim world can be categorized into two important blocks:

1) Rihla Hijazi-ya : This type of travel is referred to as the journey to the Holy city of Mecca and Medina, with the main intentions for spiritual purposes.

2) Rihla Sifariyya : This form of travel is mostly related to the diplomatic and somewhat secular goal of travel such as study or search for knowledge in several foreign places, including Cairo in modern Egypt and Istanbul in modern Turkey [33].

Moreover, over many centuries Muslims have often combined mundane and spiritual goals in their rihla, which is mainly in the form of visiting several places along the way to the Holy city of Mecca and Medina, depending on their areas of origin [34]. The forms of leisure activity, as well as travel in the Muslim world, are non-identical. Indeed, education, as well as affluence, are the distinct factors that influence Muslims to travel abroad. This review, however, exemplifies impecunious people mostly travelling for a religious purpose such as the Hajj rather than another form of leisure travel, whereas for the middle class, international pursuits such as golf, tennis, horse riding and skiing, while travelling home and abroad (for non-religious reasons) is popular [35].

Despite that, the purpose of travel may be religious or mundane. There are still certain codes of conduct based on the Islamic law that regulate Muslims behavior as guests and hosts in world tourism [26]. These codes prohibit public displays of affection, shaking hands or any physical contact between members of the opposite sex, unmarried couples sharing rooms, gambling, breaking fast in daylight during holy month of Ramadan, consumption of pork and others haram (forbidden) foods, selling or drinking liquor and dressing inappropriately, which may seem odd or even contrast with the nature of international tourism from the Western perspective. Thus, most of the Muslim outbound tourists prefer to visit tourist destinations that share similar Islamic values or often labeled as Islamic tourism [26].

Al-Hamarneh and Steiner [36] study on tourism in the MENA countries explained the terminology of Islamic tourism was first introduced by Abdel-Sahib Al-Shakry during the UNESCO International Conference on Cultural Tourism held in Damascus, just a couple hours before the 9/11 attack occurred in the USA. Originally, this terminology consisted of nine points, which can be seen in the following three main concepts:

a. The Economic Concept

Islamic tourism is seen as an extension and expansion-oriented concept which focuses on the importance of intra-Muslim and intra-Arab tourism [37]. Indeed, the tourist movement in the same region has obviously become an important factor for destination recovery in several MENA countries from the downturn in international tourist arrivals after the 9/11 attack. 
b. The Cultural Concept

Islamic tourism is described as the reaction to protect Muslims and the Arab traditional culture and cultural heritage from the issue of commodification as well as the obvious threat of aggressive neo-liberal globalization in the form of McDonaldization or Cocalization [37].

c. The Religious-conservative concepts

This concept may be described as community tourism where all elements of the modern tourism amalgam are shaped with the Islamic values in order to give a familiar feeling among Muslim tourists and avoid the hassle of being under durable lifestyle pressure in liberal and west style tourism location [37].

Some scholars noted the growth of Islamic tourism after the $9 / 11$ attack and argue impetuses related to the trend [38]. First, the spiritual intention to heighten solidarity among Ummah (the Muslim community). Second, related to the behavior of Muslims tourists that incorporate some possible leisure activities in their religious travel and last, the rigid visa regime in numerous countries, particularly the USA and most European countries because of the fear of potential threats from extremists after the $9 / 11$ attack has led to the increasing number of Muslim tourists holiday in Muslim (sic) countries such as Malaysia [38].

However, there are some formidable barriers that may affect the future development of Islamic tourism, these ranging from the political and economic condition in the MENA regions to the complexity of subjective individual tourist and country interpretation and application of Islamic law that may vary [39]. Furthermore, Henderson $[39,40]$ also criticizes the definitional ambiguities in the concept of Islamic tourism that are often used interchangeably with several terminologies as shown in Table 3. Yet, this issue of ambiguity has attracted some reputable scholars to distinguish and determine a proper definition in their studies and conceptual papers:

a. Duman [41]; Motivation is the essential factor to distinguish between Islamic and Halal tourism since motivation is essential for all Muslim [41] as mentioned by Prophet Muhammad PBUH Hadith in Sahih alBukhari: the reward deeds depend on upon the intentions and every person will get the reward according to what he/she has intended. Furthermore, this paper proposed a definition of Islamic tourism as the activities of Muslims traveling to and staying in places outside their usual environment for not more than one consecutive year for participation in those activities that originate from Islamic motivations which are not related to exercise of an activity remunerated within the place visited [42] and a definition of Halal tourism as all the goods and services of the tourism industry designed according to Islamic principles and offered to Muslim markets [41].

Table 3. Terminologies Used in Academic Papers

\begin{tabular}{l|l}
\hline \multicolumn{1}{c|}{ Terminology } & \multicolumn{1}{c}{ Author } \\
\hline Sharia tourism & Asih and Asih [42] \\
\hline Mosque tourism & Kessler [43] \\
\hline Halal-friendly & 1. Jaswir and Ramli [23] \\
hourism \& & 2. Zulkifli et al [44]
\end{tabular}

Source: Secondary documents

b. Ryan [60]; Islamic tourism primarily refer to travel undertaken for religious and pilgrimage purposes and is associated with acts of faith relating to the Islamic religion, for instance, the Hajj, Ryan goes on to say that Halal tourism is a form of tourism that is undertaken for recreational, leisure and social purposes, and a member of the Islamic faith travel(s) for the same reasons that many of us wish to travel. Reasons that may include the intention to experience the cultural diversity as well appreciate the beauty of God creation [60].

c. El-Gohary [15]; Even though Halal tourism and Islamic tourism are rooted in the Islamic law, they are different. Moreover, the term Islamic only can be used if all travel elements, including the tourist, products, 
and services are fully adherencewith the Islamic law, for example, the Hajj and the Umrah. Halal tourism in this paper is considered as a subcategory of religious tourism, a definition that is more preferable to brand and describes the tourism activities, products, and services that are un-prohibited according to Islamic law but without neglecting the need of other tourists [15].

d. Battour and Ismail [54]; The use of Islamic or Halal tourism to generalize to all forms of travel that occur in the Islamic world or conducted by Muslims is improper because of dissimilar meanings for both terminologies according to Islamic law. In fact, the term Islamic refers to an activity conducted solely for pleasing God, whereas Halal tourism is defined as any tourism object or action which is permissible to Islamic teachings to use or engage by Muslims in tourism industry that might take place outside the Muslim world in the form of hotels, resorts, restaurants, and trips [54]. Therefore, Battour and Ismail suggest that it would be better to use Halal as a brand name rather than Islamic for any related product and service in tourism industry [54].

Based on the discussion above, this present research adopts a similar, broad notion of Halal tourism, which is conducted for recreational purposes by Muslims, and applies to all related tourism activities, products, services which are considered permissible according to Islamic law that is rooted in the Holy Qur'an, Sunnah, ljma, and Ijtihad [14,20,54]. In addition, El Gohary [15] argues that Halal tourism has grown faster than any other form of travel and is projected to continue its growth. Moreover, according to the Reuters and Standard report [61], in 2014 the total valuation of the Halal tourism market (excluding the Hajj and Umrah) was exceeded USD 140 billion or counting for $11 \%$ of total world expenditure on travel and tourism. Furthermore, according to this report, the top countries in terms of tourist expenditure in Halal tourism are mostly the member countries of the Organization of Islamic Cooperation (from here referred as the OIC) from the MENA region that represent more than USD 52 billion or $35 \%$ of the global Muslim tourist expenditure, as illustrated in the following table (Table 4).

Moreover, the MasterCard and Crescent Rating [8] projected that in 2020 the number of international inbound Muslim tourists will surpass 150 million arrivals with total expenditure approximately will reach USD 330 billion worldwide. This promising number is possible because of several factors including the rapid growth of the Muslim population that faster than any other world religions as shown in Table 5.

Table 4. Main Countries in terms of Tourist Expenditure

\begin{tabular}{clc}
\hline Rank & Country & Expenditure (billion USD) \\
\hline 1 & Saudi Arabia & 17.8 \\
2 & The UEA & 12.6 \\
3 & Kuwait & 9.7 \\
4 & Qatar & 9.5 \\
5 & Indonesia & 7.6 \\
6 & Iran & 7.5 \\
\hline
\end{tabular}

Source: Thomson Reuters and Dinar Standard [61]

Table 5. Projected Growth of Major Religious Group

\begin{tabular}{|c|c|c|c|c|}
\hline $\begin{array}{l}\text { Religious } \\
\text { group }\end{array}$ & $\begin{array}{c}2010 \\
\text { population } \\
(000)\end{array}$ & $\begin{array}{c}\text { Projected } \\
2050 \\
\text { Population } \\
(000)\end{array}$ & $\begin{array}{l}\text { \% of world } \\
\text { population } \\
\text { in } 2050\end{array}$ & $\begin{array}{c}\text { Population } \\
\text { growth } \\
2010-2050 \\
(000) \\
\end{array}$ \\
\hline Christians & 2.168 .330 & 2.918 .070 & 31.4 & 749.740 \\
\hline Muslims & 1.599 .700 & 2.461 .480 & 29.7 & 1.161 .780 \\
\hline Unaffiliated & 1.131 .150 & 1.230 .340 & 13.2 & 99.190 \\
\hline Hindus & 1.032 .210 & 1.384 .360 & 14.9 & 352.140 \\
\hline Buddhists & 487.760 & 486.270 & 5.2 & -1.490 \\
\hline $\begin{array}{l}\text { Folk } \\
\text { Religions }\end{array}$ & 404.069 & 449.140 & 4.8 & 44.450 \\
\hline $\begin{array}{l}\text { Other } \\
\text { Religions }\end{array}$ & 58.150 & 61.450 & 0.7 & 3.300 \\
\hline Jews & 13.860 & 16.090 & 0.2 & 2.230 \\
\hline $\begin{array}{l}\text { WORLD } \\
\text { POPULATION }\end{array}$ & 6.895 .850 & 9.307.190 & 100 & 2.411 .340 \\
\hline
\end{tabular}

Source: PEW Research Centre [62].

The MasterCard and Crescent Rating [8] also mentioned several other impetuses for the rapid growth of Halal tourism such as the significant growth of middle-income households in several member countries of the OIC, including, among others, Turkey, Malaysia, and Indonesia. Next is the multiplication of tourism amalgams that adhere to Islamic law in IOC member countries and non-member. Next is the growing popularity of Ramadan travel as well as Business travel in Indonesia, Turkey, Malaysia, and Gulf Cooperation Council (from here referred as the GCC) member states. Lastly, the rapid growth of information and communication, especially the internet and smartphone in several MENA countries are positively contributing to increasing access to travel and tourism information.

Despite the fact that many countries have been trying to promote their tourist destination as a halal tourism destination in order to capitalize on the growth of Muslim tourists, the main destinations for Muslim tourists are still concentrated in IOC member countries [13]. 
Nevertheless, according to the World Economic Forum report on tourism competitiveness, the growth in major halal tourism destinations did not significantly improve those destinations global tourism competitiveness, except for Indonesia as shown in Table 6.

Table 6. Top Five OIC member countries

\begin{tabular}{lccc}
\hline Economy & Rank & Score & Change since 2013 \\
\hline The UEA & 24 & 4.43 & 4 \\
Malaysia & 25 & 4.41 & 9 \\
Qatar & 43 & 4.09 & -2 \\
Turkey & 44 & 4.08 & 2 \\
Indonesia & 50 & 4.04 & 20 \\
\hline
\end{tabular}

Source: World Economic Forum [63]

According to the COMCEC, the insignificant improvement in the majority of the top five OIC countries may relate to the absent or weak publicity, promotion and mass media exposure due to the limited communication systems and technological services are obstacles for tourism development in the OIC Member Countries [14]. Therefore, in their latest Tourism Outlook, the COMCEC is encouraging OIC Member Countries to improve their tourism promotion in order to make their destination more visible and efficient to compete in the international tourism market through electronic media, including CD-ROM maps, the Internet, websites, etc. [13]. In fact, approximately 250 to 287 million Muslims are online today [64]. Therefore the use of the internet for promoting Halal tourism destination is vital, especially for websites that play an essential role to stimulate and form images that shape destination perceptions and choices [65]. Indeed, websites also offer a unique way to promote religious heritage through destination image [4].

In addition, researchers argue that defining the term destination image is not an easy task; rather, it is even problematic [66] for tourism researchers because it lacks a solid conceptual structure [67]. Particularly, in the term image that has already been used in various contexts and disciplines, which leads to unclear definition [68]. Nevertheless, some of the prominent tourism scholars have argued that the destination image could be defined as the impression that people hold about a state in which they do not reside [69], while Crompton argues that destination image is the sum of beliefs, ideas, and impressions that people associate with a destination [70] that usually takes form in a set of attributes [71]. Furthermore, the images of a destination are formed from organic, induced and modified induced image [66]. The first image are related to various non-commercial information ranging from television documentaries, books, school lesson(s) and stories of friends' experience that may not be exclusively developed for attracting visitation but have a strong contribution to the overall destination image. Next is the induced image, which is designed solely for promoting a tourism destination.

Lastly, the modified induced image is the outcome of personal visitation from a particular tourism destination. Destination image is constructed from three components that are interrelated [72]. The first component, cognitive, is related to individual motivation to visit a particular destination. The second component, affective, is related to personal emotions or sentimental feelings about a particular destination. The last component is conative, which is constructed from the cognitive and the affective component after the visitation and may take forms of, for example, re-visitation or giving a recommendation. Moreover, the initial image formation stage before the trip is the most important phase in tourist destination selection process [73] and, therefore, it should be the focus of attention for the NTOs and DMOs.

With the absence of visitation experience in this phase, there are three main determinants that construct destination image including the socio-demographic factors as well as the information sources, which are represented by the stimulus variables. The latter determinants consist of two important variables including the social stimuli or word-of-mouth communication, and the symbolic stimuli that are referred to in a destination marketing campaign through various media such as brochure, guide book, and website that are intentionally developed to influence the tourist's perceived image of a place or destination [73]. Specifically for tourism organizations that plan to target Muslims tourists, some researchers argue that these organizations should consider having Islamic attributes that meet traveler' needs, attributes that adhere to Islamic law [71]. As an example, the impact of destination attribute on Muslim tourists' choice in Malaysia has successfully identified two major Islamic attributes of destinations that may attract Muslim tourists [48]. The first is the tangible attribute that includes the availability and access to worship or prayer facilities and the availability of Halal food. The second is the intangible attribute that ranges 
from Islamic entertainment, Islamic dress codes, general Islamic morality and Islamic call for prayer. However, the latter attribute is only limited to Muslim countries because these aspects are not realistic within non-Muslim societies [48]. Therefore, several Islamic attributes of destinations are added in order to attract more visitations and cater to the needs of Muslim tourists [51], as exemplified in Table 7.

\begin{tabular}{cl}
\multicolumn{2}{c}{ Table 7 Tourism destination Islamic attributes } \\
\hline No. & \multicolumn{1}{c}{ Attributes } \\
\hline 1 & $\begin{array}{l}\text { Availability of mosque (Masjid) } \\
\text { Availability of prayer facilities at tourism sites, } \\
\text { airport, hotels, etc. }\end{array}$ \\
3 & $\begin{array}{l}\text { Presence of loud pronouncement of prayer } \\
\text { calling time }\end{array}$ \\
4 & $\begin{array}{l}\text { Placement of Qiblah stickers - direction point } \\
\text { towards Mecca }\end{array}$ \\
5 & $\begin{array}{l}\text { Availability of water supply in toilets at tourist } \\
\text { sites, airport, etc. }\end{array}$ \\
6 & $\begin{array}{l}\text { Availability of Halal food at tourism sites, airport, } \\
\text { shopping, etc. }\end{array}$ \\
7 & $\begin{array}{l}\text { Availability of segregated Halal kitchen in hotels } \\
\text { and restaurants }\end{array}$ \\
8 & $\begin{array}{l}\text { Availability of segregated areas for women at } \\
\text { beaches }\end{array}$ \\
9 & $\begin{array}{l}\text { Availability of segregated swimming pools and } \\
\text { gymnasium }\end{array}$ \\
10 & $\begin{array}{l}\text { Banning of alcoholic drinks by the authorities at } \\
\text { public places } \\
\text { Banning of sex channels on hotel entertainment } \\
\text { system }\end{array}$ \\
\hline
\end{tabular}

Source: Battour et al [51]

Moreover, based on the researcher's knowledge, several Halal tourism destinations have been trying in their marketing campaigns to use text and pictures that depict the Islamic attributes to develop a positive image that could influence Muslim tourist destination choice, as exemplified in Table 8. Nevertheless, the existing study on online destination promotion in halal tourism main destination is still limited. It is especially the case for Indonesia as the world's biggest Muslim country $[28,74]$ and the world's emerging halal tourism destination $[8,13,75]$. Only two studies of Halal tourism destination image promotion have been conducted in Indonesia by Henderson [45] and Chabbra [4]. Of the research, they all only examine texts and pictures depicting Islamic attributes of destinations from secondary sources of information owned by the MTRI, which is Indonesia's NTO.

Given several reasons mentioned above, this study aims to add to the scant studies on halal tourism destination promotion in Indonesia by examining the website that is officially owned by
Destination Management Organization (from here referred as the DMO). Furthermore, to gain a proper understanding of halal tourism promotion, this research proposes research questions on how do Indonesia halal tourism destinations promoted through the DMOs' official websites. And how do the Indonesian Halal tourism DMO websites differ among themselves in promoting tourism.

Table 8. Summary of Studies on the Image of Halal Tourism Destination

\begin{tabular}{|c|c|c|c|}
\hline Author & Country(s) & $\begin{array}{l}\text { Islamic } \\
\text { Attributes }\end{array}$ & Sample \\
\hline Henderson & Malaysia & $\begin{array}{l}\text { Islamic } \\
\text { museum }\end{array}$ & $\begin{array}{l}\text { NTO's } \\
\text { website }\end{array}$ \\
\hline $\begin{array}{l}\text { Hashim, } \\
\text { Murphy, and } \\
\text { Hashim }\end{array}$ & Malaysia & $\begin{array}{l}\text { 1. Islamic arts } \\
\text { and } \\
\text { architecture } \\
\text { 2. Islamic } \\
\text { festival } \\
\text { 3. Islamic dress } \\
\text { code } \\
\text { 4. Prayer times } \\
\text { 5. Halal food } \\
\text { information } \\
\text { 6. Travel tips on } \\
\text { Muslim } \\
\text { conduct, } \\
\text { 7. Non-Islamic } \\
\text { conduct (such } \\
\text { as gambling } \\
\text { /casino) }\end{array}$ & $\begin{array}{l}\text { Official } \\
\text { tourism } \\
\text { website from } \\
15 \text { Malaysian } \\
\text { regional } \\
\text { states }\end{array}$ \\
\hline Henderson & $\begin{array}{l}\text { Egypt } \\
\text { Malaysia } \\
\text { Morocco } \\
\text { Tunisia } \\
\text { Turkey } \\
\text { The UEA } \\
\text { (Dubai) } \\
\text { Indonesia }\end{array}$ & $\begin{array}{l}\text { 1. Mosque } \\
\text { architecture } \\
\text { 2. Festive food } \\
\text { 3. Colorful } \\
\text { event and } \\
\text { sights }\end{array}$ & $\begin{array}{l}\text { NTO's } \\
\text { Website and } \\
\text { Printed } \\
\text { Brochure }\end{array}$ \\
\hline Chhabra & $\begin{array}{l}\text { Saudi } \\
\text { Arabia } \\
\text { Indonesia } \\
\text { Algeria } \\
\text { Maldives } \\
\end{array}$ & $\begin{array}{l}\text { 1. Islamic } \\
\text { clothing } \\
\text { guideline and } \\
\text { Abaya } \\
\text { 2. Travel tips }\end{array}$ & $\begin{array}{l}\text { NTO's } \\
\text { Website }\end{array}$ \\
\hline $\begin{array}{l}\text { Akyol and } \\
\text { Kilinc }\end{array}$ & Turkey & $\begin{array}{l}\text { 1. Halal food \& } \\
\text { non-alcohol } \\
\text { principles } \\
\text { that shown } \\
\text { with the Halal } \\
\text { certificate } \\
\text { 2. Separate } \\
\text { facilities for } \\
\text { women } \\
\text { 3. Prayer rooms }\end{array}$ & $\begin{array}{l}\text { Website of } 5 \\
\text { local hotels } \\
\text { in Turkey }\end{array}$ \\
\hline
\end{tabular}

Source: Secondary documents

\section{METHOD}

In order to understand online halal tourism promotion in Indonesia, the present research is following the interpretive paradigm and adopts 
qualitative content analysis as the tool to investigate halal tourism promotion in Indonesia. The interpretive set of beliefs was chosen as the research paradigm because of its focus to seek understanding rather than focus on the issue of emancipation from oppression or technical control [76]. While the qualitative form of content analysis was chosen because of several considerations, ranging from the nature of content analysis that is suitable for examining tourism marketing and communication activities to previous research on halal tourism in Indonesia that adopt the same tools to examine official tourism organization websites $[4,45,77,78,79]$. Moreover, this research employ a census study to examine the entire population (N), which is the homepages of the official websites of DMOs according to Indonesia's national plan on halal tourism that was first announced by the MTRI as shown in Table 9.

Table 9 Indonesia's Halal tourism Destinations

\begin{tabular}{cc}
\hline & Regions \\
\hline Aceh & East Java \\
West Sumatra & Central Java \\
Riau & West Java \\
Riau Archipelago & Jakarta \\
South Sulawesi & West Nusa Tenggara \\
\hline
\end{tabular}

Source: Yahya [7]

Furthermore, the official websites' homepages were selected as the unit of analysis for several reasons. Firstly, general tourism research on website content analysis has often employed specific website pages such as homepage as the research unit of analysis [8083]. Secondly, previous studies on the image of Halal tourism destination use homepage as the unit of analysis in order to avoid bias due to the differences in website size and page $[4,45,65]$. In order to identify the English-language websites exclusively developed to promote regional tourism, the researcher first searched for the website names in the directory of Dinas Pariwisata available at kemenpar.go.id [84]. Despite the fact that all regional tourism office websites listed in the MTRI website are owned and run by the designated regional tourism offices, some of them are neither exclusively developed to promote tourism nor equipped with an English version. Hence, the researcher needed to scrutinize links in each website and run a series of searches to locate the websites based on data from kemenpar.go.id as well as the keywords tourism, travel and the DMOs or Indonesia's Halal tourism destinations name. e.g.
Aceh, West Sumatra, Jakarta, West Java, Central Java, East Java, Jogjakarta, Lombok, Riau, Riau Archipelago, South Sulawesi, and West Nusa Tenggara.

As a result, twenty-five websites were initially identified during the high season in Indonesia from November to January [85]. Nineteen websites were excluded in this research; however, as they do not officially belong to the DMOs, were not developed for tourism promotion, and were only available in Bahasa. Following the identification process, six websites' homepages were selected as the sample websites for further analysis including:

- bandaacehtourism.com

- wonderfullomboksumbawa.com

- jakarta-tourism.go.id

- westjavatourismboard.info

- eastjava.com,

- exploresouthsulawesi.com

In addition, prior to collecting as well as analyzing data, the researcher developed a coding frame based on previous research on halal tourism destination promotion in Indonesia and conducted a pilot study to examine official websites' homepages that were exclusively developed to promote halal tourism in three different countries: Indonesia (halaltourism.id), Japan (muslimguide.jnto.go.jp), and Malaysia (itc.gov.my). Due to the time constraint, these countries were chosen using a convenient sampling method based on the researcher's knowledge and the existing literature available. In respect of the coding frame, it is used to reduce the data by distinguishing between relevant and irrelevant data that might lead to research bias [78].

As a result, the pilot study shows that most of the destination attributes developed from previous studies on halal tourism promotion in Indonesia are relevant for examining the halal tourism destination websites in three different countries, as illustrated in Table 10.

Table 10. Islamic Attributes of Destinations in Indonesia

\begin{tabular}{cl}
\hline No. & \multicolumn{1}{c}{ Islamic attributes } \\
\hline 1 & Islamic/Muslim festival/celebration \\
2 & Islamic/Halal food \\
3 & Islamic/Muslim prayers \\
4 & Islamic/Muslim dress \\
5 & Mosque/other architecture \\
6 & Other religions / toleration \\
7 & Code of Conduct / travel advice \\
\hline Source: & Research Analysis
\end{tabular}




\section{RESULT AND DISCUSSION}

A total of six official promotional websites owned by Indonesia halal tourism DMOs were analysed qualitatively using the coding frame from previous studies on halal tourism promotion in Indonesia, as illustrated in Table 11. Based on the data shown in the table, it may be concluded that the Indonesia halal tourism DMOs are using limited forms of Islamic attributes to promote their destinations through the website. Mosque or other Islamic architecture and Islamic or Muslim Dress are the predominant Islamic attributes used in the research sample websites. Moreover, the first predominant Islamic attributes were depicted on several websites, i.e. bandaacehtourism.com, eastjava.com, westjavatourismboard.info while the latter predominant Islamic attributes were depicted in jakartatourism.go.id, bandaacehtourism.com, and westjavatourismboard.info. Following these two attributes is the Islamic or Halal food, which is depicted in Aceh's official website, the bandaacehtourism.com, and in South Sulawesi's official website, the exploresouthsulawesi.com.

\section{Indonesia Halal Tourism Destinations Promotion through the DMOs' Websites}

Generally, the majority of the research's sample websites are not yet focused on promoting halal tourism according to theoretical foundation suggested in existing studies on halal tourism and more focused on destination attributes other than the Islamic attributes. Examples of such attributes are historical sites, cultural diversity and unthreatening nature as shown in Figure 3.

Actually, this research finding may correlate to Indonesia's moderate view towards tourism [66] that influence their promotional website content, which is more devoted to their naturebased attractions [4]. Furthermore, this finding may also correlate to the previous research that has examined NTO's website, research noting that Islam is acknowledged in all the sources consulted, with the exception of the Indonesian website [45].

In addition, for the most part, mosque or other Islamic architecture, Islamic or Muslim dress followed with Islamic or Halal food are the predominant Islamic attributes depicted in the sample websites to induced a positive image of a halal tourism destination. This finding is similar to the results from the pilot test that examined halal tourism websites in three different countries including Indonesia. This similarity might occur related to a finding from Battour et al [48] study that concluded prayer facilities, halal food, and Islamic dress code are among the tangible and intangible Islamic attributes of destinations that may attract Muslims tourists.

\section{Indonesian Halal Tourism DMO Websites Differ Themselves in Promoting Tourism}

Of all the halal tourism destination websites, Aceh uses the most Islamic attributes in bandaacehtourism.com. This dominant use of Islamic attribute may be linked to the enactment of the Special Autonomy Law in Aceh, which gives the local government the authority to enact a series of local laws or qanuns to govern the implementation of Islamic law $[86,87]$. Furthermore, the bandaacehtourism.com use various Islamic attributes to create a positive image in Muslim tourists' minds including Islamic or Muslim festival celebration, Islamic food or Halal food, Islamic or Muslim prayers, Islamic or Muslim dress, and Mosque or other Islamic architecture (Figure 4).

Table 11. Indonesia Halal Tourism Destination Website

\begin{tabular}{|c|c|c|c|c|c|c|c|c|c|c|c|c|c|}
\hline \multirow{2}{*}{\multicolumn{2}{|c|}{ Islamic Attributes of Destination }} & \multicolumn{12}{|c|}{ Indonesia Halal Tourism Destination Website } \\
\hline & & \multicolumn{2}{|c|}{ Jakarta } & \multicolumn{2}{|c|}{ Lombok } & \multicolumn{2}{|c|}{ Aceh } & \multicolumn{2}{|c|}{ West java } & \multicolumn{2}{|c|}{ Sulawesi } & \multicolumn{2}{|c|}{ East java } \\
\hline & & $\mathbf{T}$ & $\mathbf{P}$ & $\mathbf{T}$ & $\mathbf{P}$ & $\mathbf{T}$ & $\mathbf{P}$ & $\mathbf{T}$ & $\mathbf{P}$ & $\mathbf{T}$ & $\mathbf{P}$ & $\mathbf{T}$ & $\mathbf{P}$ \\
\hline 1 & Islamic/Muslim festival celebration & - & - & - & - & $*$ & * & - & - & - & - & - & - \\
\hline 2 & Islamic/Halal food & - & - & - & - & $*$ & $*$ & - & - & $*$ & $*$ & & \\
\hline 3 & Islamic/ Muslim prayers & - & $*$ & - & - & - & - & - & - & - & - & - & - \\
\hline 4 & Islamic/ Muslim dress & - & $*$ & - & - & - & $*$ & - & $*$ & - & - & - & - \\
\hline 5 & Mosque/other Islamic architecture & - & - & - & - & $*$ & $*$ & - & $*$ & - & - & $*$ & - \\
\hline 6 & Other religions/toleration & $*$ & $*$ & - & - & - & - & - & - & - & - & $*$ & $*$ \\
\hline 7 & Code of Conduct/travel advice & - & - & - & - & - & - & - & - & - & - & - & - \\
\hline
\end{tabular}

Notes: *(Available), - (Not Available), T (Text), and P (Picture) 


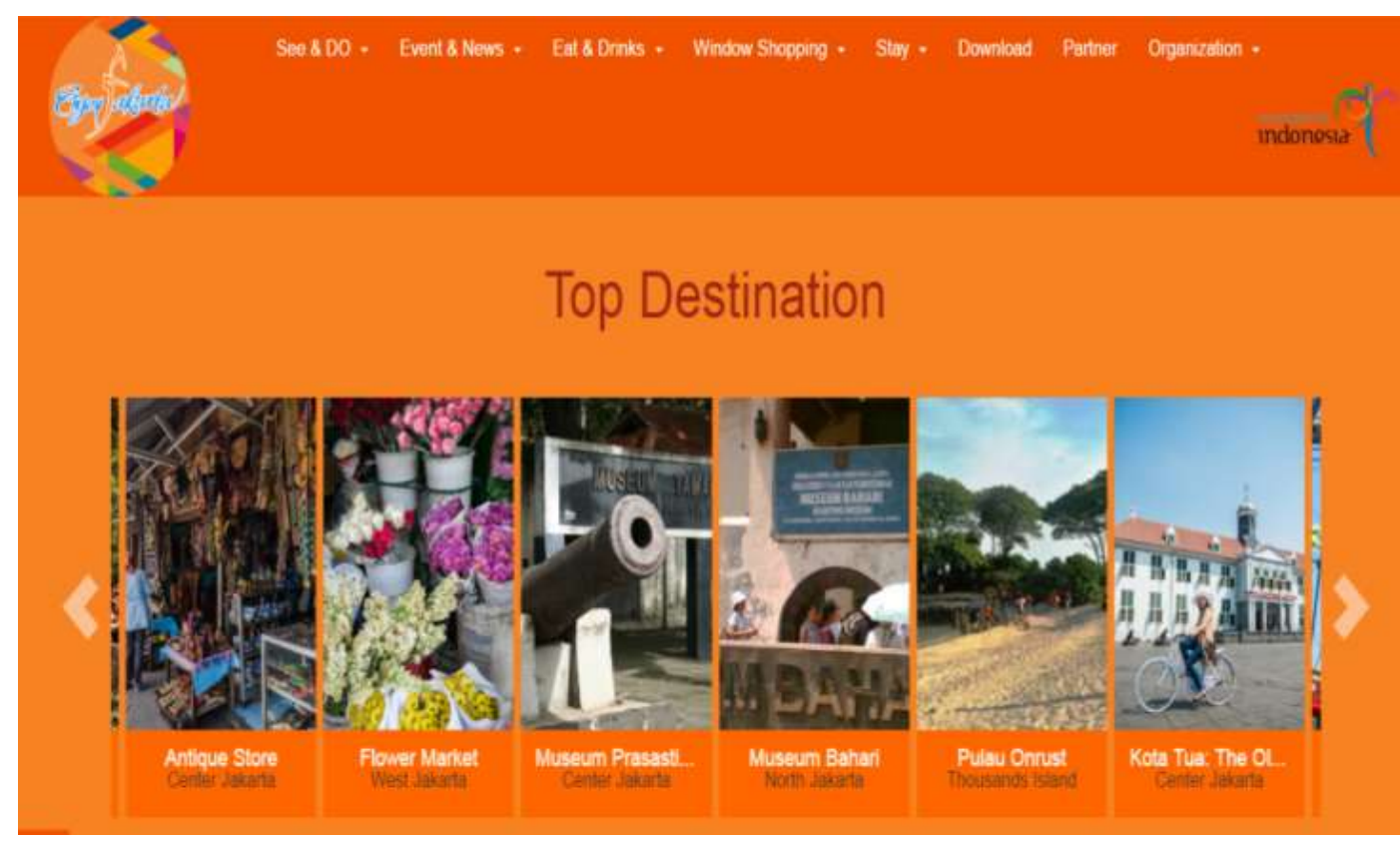

Figure 3. Special Administrative Capital Region of Jakarta Tourism Promotion Website

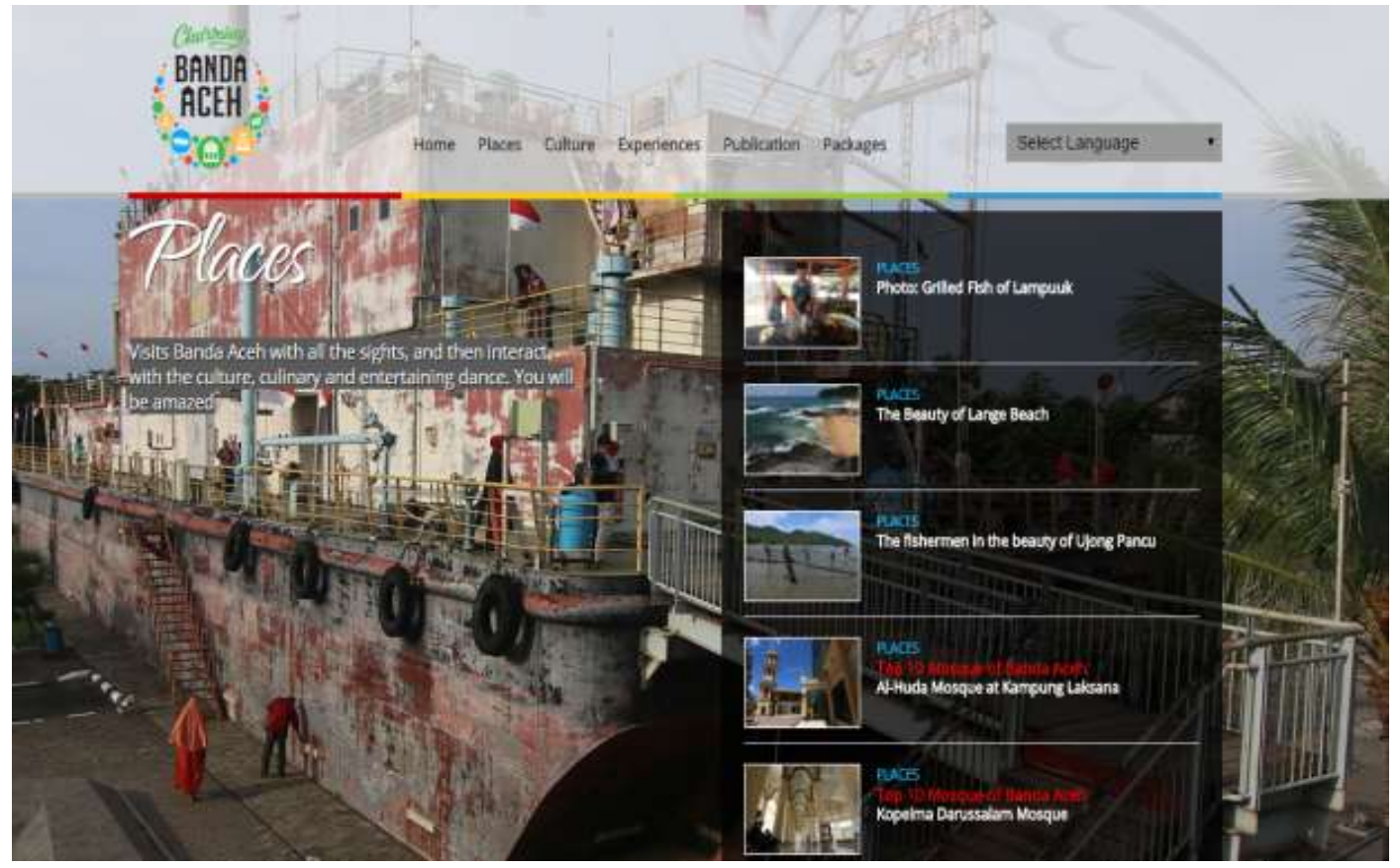

Figure 4. Banda Aceh Official Tourism Promotion Website

On the contrary, the website wonderfullomboksumbawa.com, as the official promotional website of West Nusa Tenggara, is the only sample website that prefer to focuses on other destination attributes rather than the Islamic attributes. Moreover, the website wonderfullomboksumbawa.com uses several pictures and texts related to natural and cultural attractions to attract tourist visitation, as shown in Figure 5. This finding is surprising given that Lombok as one of West Nusa Tenggara's popular tourism destination won the 2015 World Halal Tourism Awards.

However, if considering the history of tourism in West Nusa Tenggara, especially that of Lombok that for a significant period has been promoted under Beyond Bali national marketing campaign $[88,89]$ as the Indonesia's second Bali for its nature-based attractions [90]. This phenomenon of focusing on attributes other than those Islamic, becomes relevant. Moreover, this phenomenon is similar to the results 
reported by Henderson [45] suggesting that the Islamic attributes in official destination websites are often overshadowed by other destination attributes.

On the other hand, the rest of the sample websites in this research give limited space for depicting Islamic attributes of destination compared to the space that given to text and pictures depicting destination attributes related to their natural attractions or cultural heritage as illustrated in Figure 6. This finding is akin to the finding from research on Malaysia's state tourism DMOs that showed minimal, albeit varying, portrayals of Muslim values on the DMO website [65].

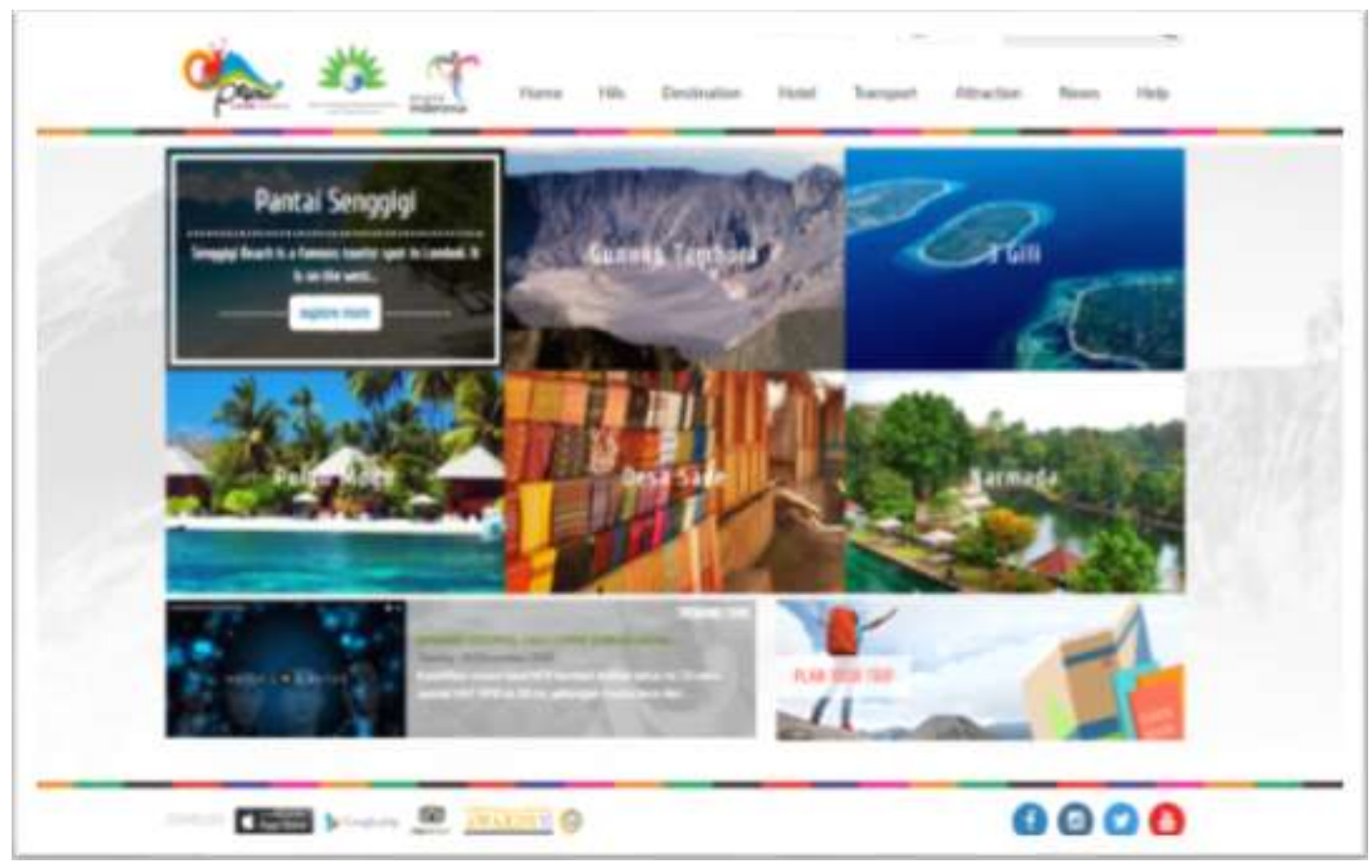

Figure 5. West Nusa Tenggara Official Tourism Promotion Website

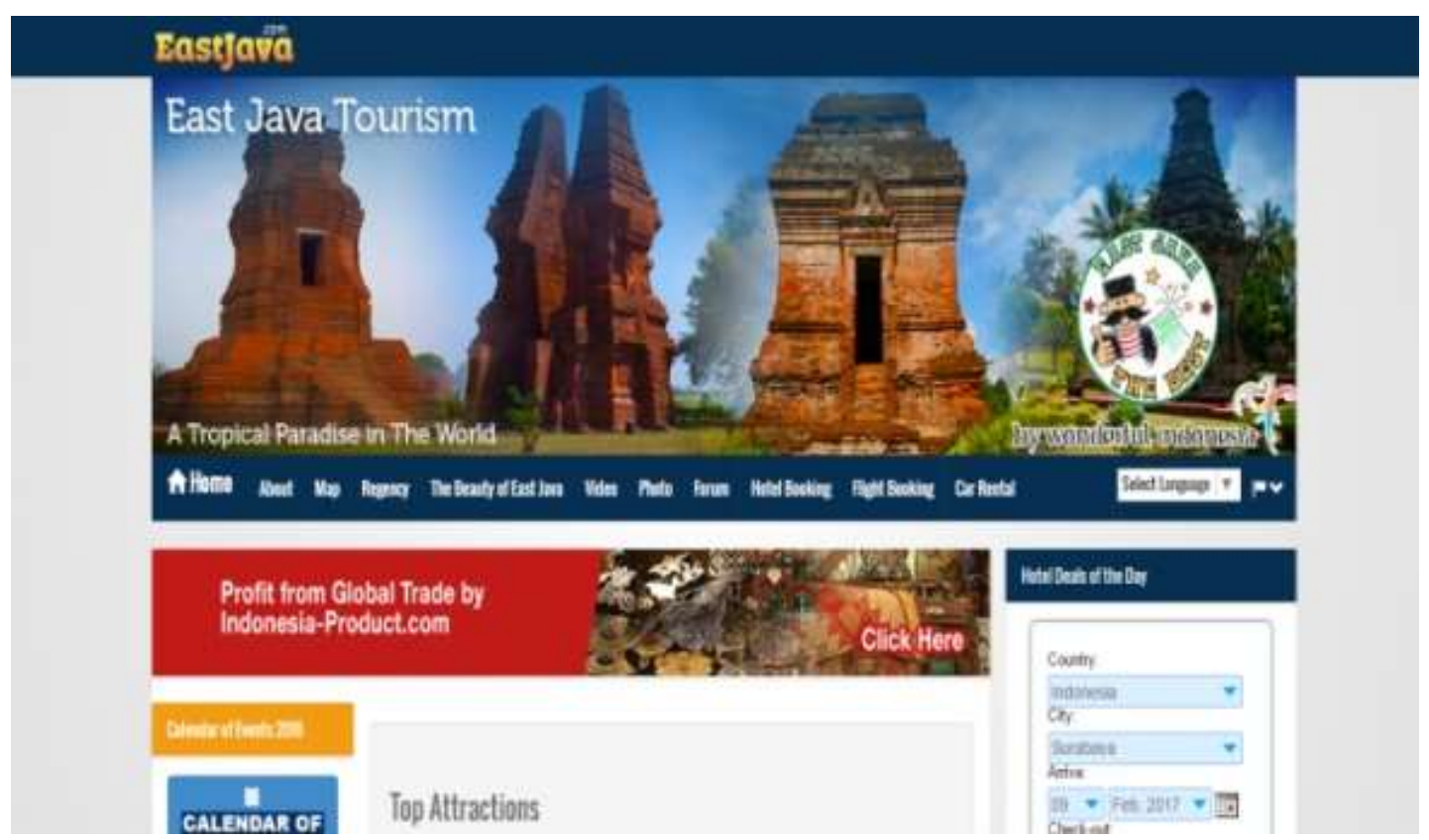

Figure 6 East Java Official Tourism Promotion Website 


\section{CONCLUSION}

The results shown that except in Aceh's sample website, the Islamic attributes of destination used in the DMOs websites are unfortunately overshadowed by other destination attributes for several reasons. The first is related to tourism regulation or plan at the regional level, neither of which are coordinated with the national Halal tourism master plan and regulation developed at the central government level. The second reason is concerned with Indonesia being a multicultural country blessed with diverse landscapes and native wildlife; given this richness, the country's tourism organizations have tended to focus on promoting their natural and cultural wonders. Third, despite the fact that Islam is the predominant religion in Indonesia's Halal tourism destinations, some of those destinations are famous for tourist attractions that are related to other religions such as Borobudur and Prambanan temple. Last, the strong image of Bali as a world-class tourism destination has influenced the development and marketing campaigns of some Indonesia Halal tourism destinations.

Nevertheless, this study is vital for several reasons. First, it extends Chhabra [4] and Henderson [45] studies of Indonesia tourism images as a Muslim tourist destination from national tourism organization level to destination management organization level. Second, it extends discussion on the online Image of Halal Tourism Destination $[4,45,54,65]$. Third, the results derived from this study could give the central government an insight into how the regional DMOs respond to the Indonesia Halal tourism master plan and perhaps encourage the central government to develop an additional program to enhance the regional government awareness and understanding on Halal tourism in a manner that would coordinate with the national plan.

\section{REFERENCES}

[1] Ministry of National Development Planning (Bappenas), Statistics Indonesia (BPS) and UN Population Fund. 2013. Proyeksi penduduk Indonesia 2010-2035. Available at: www.bappenas.go.id/files/5413/9148/ 4109/Proyeksi_Penduduk_Indonesia_20102035.pdf

[2] Luthfi, B. A. and I. Salehudin. 2011. Marketing impact of halal labeling toward Indonesian muslim consumer's behavioral intention. Asean Marketing Journal III(1), 35-44.

[3] World Bank. 2016. Indonesia: overview. Available at: http://www.worldbank.org/ en/country/indonesia/overview.

[4] Chhabra, D. 2010. Chapter 17: Islamicization of promotion. In: Scott, N. and J. Jafari (Eds). Tourism in the Muslim World. 267-285.

[5] Nirwandar, S. 2015. Halal lifestyle in Indonesia. Paper presented at The UNWTO Seminars - The Contribution of Islamic Culture and its Impact on the Asian Tourism Market. Brunei Darussalam.

[6] Nirwandar, S. 2016. Road to Halal tourism and halal lifestyle. Paper presented at the International Seminar on Halal Tourism. Bandung. West Java.

[7] Yahya, A. 2016. Percepatan pengembangan wisata halal di Indonesia. Paper presented at the Internasional Seminar on Halal Tourism. West Java.

[8] MasterCard and CrescentRating. 2017. Global muslim travel index 2017. Available at: newsroom.mastercard.com/asiapacific /files/2017/05/Report-MastercardCrescentRating-GMTI-2017-20mb.pdf

[9] World Travel and Tourism Council. 2017. Travel and tourism economic impact 2017 Indonesia. Available at: www.wttc.org//media/files/reports/economicimpactresea rch/countries-2017/indonesia2017.pdf.

[10] Bureau of Public Law and Communication (Biro Hukum dan Komunikasi Publik). 2015. Siaran Pers Kado 1 Tahun Pemerintahan Presiden Jokowi-JK dari Kemenpar RI Sabet 3 Penghargaan di World Halal Travel Summit $2015 . \quad$ Available at: www.kemenpar.go.id/asp/detil.asp?c=16\&i $d=2998$.

[11] Yahya, A. 2016. Percepatan pengembangan wisata halal di Indonesia. Paper presented at Seminar KOMPAS Wisata Halal Dunia: Daya Tarik Indonesia sebagai Wisata Halal Dunia. West Nusa Tenggara.

[12] Ministry of Tourism of the Republic of Indonesia. 2016. Halal tourism industry vie for World Halal Tourism Award 2016. Available at: www.indonesia.travel/en/ post/indonesia-s-halaltourism-industry-viefor-world-halal-tourism-awards-2016.

[13] Standing Committee on Economic and Commercial Cooperation of the Organization of Islamic CooperationCOMCEC. 2015. COMCEC Tourism Outlook. 
Available at: http://www.mod.gov.tr/Lists/ RecentPublications/Attachments/86/COMC EC\%20TOURISM\%20OUTLOOK-2015.pdf. 28-29.

[14] Al Jallad, N. 2008. The concepts of al-halal and al-haram in the Arab-Muslim culture: a translational and lexicographical study. Language Design: Journal of Theoretical and Experimental Linguistics 10, 77-86.

[15] El Gohary, H. 2015. Halal Tourism, is it really Halal? Tourism Management Perspectives 19(B), 124-130.

[16] Muhammad, N. 2011. Fatwa rulings in Islam: a Malaysian perspective on their role in Muslim consumer behavior. In: Sandıkcı, Ö. and G. Rice (Eds). Handbook of Islamic marketing, 35-54.

[17] Haleem, M. A. 2005. The Qur'an: a new translation by M. A. S. Abdel Haleem. University of Oxford. Oxford.

[18] Leach, H. 1990. Observing Islam from within and without. Asian Affairs 21(1), 3-19.

[19] Sanad, H. S., A. M. Kassem and N. Scott. 2010. Chapter 2 Tourism and Islamic law. In: Scott, N. and J. Jafari (Eds). Tourism in the Muslim World. 17-30.

[20] Esposito, J. L. 2002. What everyone needs to know about Islam. University of Oxford Press. Oxford.

[21] Yap, K. B. 2011. Islamic banking: the convergence of religion, economic selfinterest and marketing. In: Sandıkcı, Ö. And G. Rice (Eds). Handbook of Islamic marketing. 226-247.

[22] Asiaei, A., A. A. Aziz and S. Zailani. 2016. The significant role of halal ports in Malaysia logistics industry. In: Manan, S. K. A., Abd. Rahman F., M. Sahri (Eds). Contemporary Issues and Development in the Global Halal Industry: Selected Papers from the International Halal Conference 2014. 347-357.

[23] Jaswir, I. and N. Ramli. 2016. Study on muslim-friendly hospitality in Malaysia. In: Ab. Manan, S., Abd Rahman F., Sahri M. (Eds). Contemporary Issues and Development in the Global Halal Industry: Selected Papers from the International Halal Conference 2014. 59-66.

[24] Khalid, M. M., M. A. Z. Yaakob, M. D. M. Sirajuddin, A. Bhari and M. Mahfot. 2016. Risk analysis in the halal food industry: an exploratory study. In: Ab. Manan S., Abd Rahman F., Sahri M. (Eds). Contemporary Issues and Development in the Global Halal
Industry: Selected Papers from the International Halal Conference 2014. 67-79.

[25] Laderlah, S. A., S. Ab. Rahman, K. Awang and Y. C. Man. 2011. A study on Islamic tourism: a Malaysian experience. The $2^{\text {nd }}$ International Conference on Humanities, Historical and Social Sciences IPEDR.17, IACSIT Press, 148-189.

[26] Ghadami, M. 2012. The role of Islam in the tourism industry. Management Arts 52, 11204-11209.

[27] Sachedina, A. 2009. Ziyarah. In: Esposito, J. L. The Oxford Encyclopedia of the Islamic world. University of Oxford. Oxford.

[28] Esposito, J. L. (Ed). 2004. The Islamic world: past and present 3 - Volume Set. Oxford University. Oxford.

[29] Yusuf, I. 2009. Tawaf. In: Esposito, J. L. The Oxford Encyclopedia of the Islamic world. University of Oxford. Oxford.

[30] Arabian Business. 2015. Number of umrah visa treble in 2016. Available at: www.arabianbusiness.com/number-ofumrah-visastreble-in-2016-608718.html.

[31] Bhardwaj, S. 1998. Non-hajj pilgrimage in Islam: A neglected dimension of religious circulation. Journal of Cultural Geography 17(2), 69-87.

[32] Samori, Z., N. Z. M. Salleh and M. M. Khalid. 2016. Current trends on Halal tourism: Cases on selected Asian countries. Tourism Management Perspectives 19, 131-136.

[33] El Moudden, A. 1990. The ambivalence of Rihla: community integration and selfdefinition in Morrocan travel accounts, 1300 - 1800. In: Eickelman, D. F. and J. Piscatori (Eds). Muslim travelers: Pilgrimage, migration, and the religious imagination. Routledge.

[34] Bianchi, R. R. 2009. Travel for religious purposes. In: Esposito, J. L. The Oxford Encyclopedia of the Islamic world. Oxford University Press.

[35] Martin, W. H., and S. Mason. 2004. Leisure in an Islamic context. World Leisure Journal 46(1), 4-13.

[36] Al-Hamarneh, A. and C. Steiner. 2004. Islamic tourism: Rethinking the strategies of tourism development in the Arab world after September 11, 2001. Comparative Studies of South Asia, Africa and the Middle East 24(1), 173-182.

[37] Al-Hamarneh, A. 2008. Islamic tourism: A long term strategy of tourist industries in the Arab World after 9/11. Centre for 
Research in the Arab World. 3-5. Available at: www.ceraw.uni-mainz.de.

[38] Scott, N. and J. Jafari. 2010. Chapter 1 Introduction. In: Scott, N. and J. Jafari (Eds). Tourism in the Muslim World, 1-13.

[39] Henderson, J. C. 2009. Islamic tourism reviewed. Tourism Recreation Research 34(2), 207-211.

[40] Henderson, J. C. 2010. Chapter 6: Islam and tourism. In: Scott, N. and J. Jafari (Eds). Tourism in the Muslim World. 75-89.

[41] Duman, T. 2012. The value of Islamic tourism: perspectives from the Turkish experience. Islam and Civilizational Renewal (ICR) 3(4), 718-739.

[42] Asih, S. M. and S. K. Asih. 2015. Marketing strategy implementation in developing Sharia tourism in Indonesia. International Proceedings of Management \&and Economy Development and Research (IPEDR).

[43] Kessler, K. 2015. Conceptualizing mosque tourism: a central feature of Islamic and Religious Tourism. International Journal of Religious Tourism and Pilgrimage 3(2), Article 2. DOI: 10.21427/D7RB0G.

[44] Zulkifli, W., K. Awang, S. Ab. Rahman and Y. B. Che-Man. 2011. Developing the framework for Halal friendly tourism in Malaysia. International Business Management 5(6), 295-302.

[45] Henderson, J. C. 2003. Managing tourism and Islam in peninsular Malaysia. Tourism Management, 447-456.

[46] Henderson, J. C. 2008. Representations of Islam in official tourism promotion. Tourism, Culture and Communication 8, 135-145.

[47] Henderson, J. C. 2016. Muslim travelers, tourism industry responses \& the case of Japan. Tourism Recreation Research, 1-9.

[48] Zamani-Farahani, H. and J. C. Henderson. 2010. Islamic tourism and managing tourism development in Islamic societies: The cases of Iran and Saudi Arabia. International Journal of Tourism Research 12(1), 79-89.

[49] Battour, M., M. N. Ismail and M. Battor. 2011. The impact of destination attributes on Muslim tourist's choice. International Journal of Tourism Research 13(6), 527-540.

[50] Mohamed, H. and H. Mahmud. 2014. Promoting Islamic tourism in Brunei: through customers understanding towards the Syariah compliant hotel concepts.
Available at: eprints.nottingham.ac.uk /27242/1/HajiMohamedHajiMahmud.pdf.

[51] Battour, M., M. Battor and M. A. Bhatti. 2014. Islamic attributes of destination: Construct development and measurement validation, and their impact on tourist satisfaction. International Journal of Tourism Research 16(6), 556-564.

[52] Jaelani, A. 2016. Islamic tourism development in Cirebon: the study heritage tourism in Islamic economic perspective. Munich Personal RePEc Archive (MPRA) Paper No. 70768. Available at: mpra.ub.uni-muenchen.de/70768/

[53] Euromonitor International and World Tourism Market. 2007. The world travel market global trends reports 2007. World Travel Market. London.

[54] Battour, M. and M. N. Ismail. 2015. Halal tourism: concepts, practices, challenges, and future. Tourism Management Perspectives 19(B), 150-154.

[55] Akyol, M. and Ö. Kilinç. 2014. Internet and halal tourism marketing. Electronic Turkish Studies 9(8), 171-186.

[56] Mohsin, A., N. Ramli and B. A. Alkhulayfi. 2015. Halal tourism: emerging opportunities. Tourism Management Perspectives, 1-7.

[57] Carboni, M. and M. I.Janati. 2015. Halal tourism de facto: A case from Fez, Tourism Management Perspectives 19(B), 155-159.

[58] Abdul-Razzaq, S. 2016. Halal, New Zealand! An exploratory study into the halalfriendliness of accommodation providers in New Zealand. Master Thesis. Department of Management, Marketing, and Entrepreneurship, University of Canterbury. New Zealand.

[59] Adidaya, Y. A. 2016. Halal in Japan: history, issues, and problems. Doctoral Dissertation. University of Oslo. Norway.

[60] Ryan, C. 2015. Halal tourism. Tourism Management Perspectives 19, 121-123.

[61] Thomson Reuters and Dinar Standard. 2016. State of the global Islamic economy 2013 report. Thomson Reuters and Dinar Standard. New York City.

[62] PEW Research Centre's Forum on Religion and Public Life. 2015. The future of the world religions: population growth projections 2010-2050. Available at: www.pewforum.org/2015/04/02/religiousprojections-2010-2050. 
[63] World Economic Forum. 2015. Travel and tourism competitiveness report. Available at: http://www3.weforum.org/docs/TT15/ WEF_Global_Travel\&Tourism_Report_2015 .pdf.

[64] El-Fatatry, M., S. Lee, T. Khan, V. Lehdonvirta. 2011. A digital media approach to Islamic marketing. In: Sandıkcı, Ö. and G. Rice (Eds). Handbook of Islamic marketing. 338-360.

[65] Hashim, N. H., J. Murphy, and N. M. Hashim. 2007. Islam and online imagery on Malaysian tourist destination websites. Journal of Computer-Mediated Communication 12(3). DOI:10.1111/j.10836101.2007.00364.x.

[66] Jenkins, O. H. 1999. Understanding and measuring tourist destination images. The International Journal of Tourism Research 1(1), ProQuest Central, 1-15.

[67] Beerli, A. and J. D. Martin. 2004. Factors influencing destination image. Annals of Tourism Research 31(3), 657-681.

[68] Echtner, C. M. and J. B. Ritchie. 1991. The meaning and measurement of destination image. Journal of Tourism Studies 2(2), 212.

[69] Muttamara, S. C. 1997. Destination image of New Zealand as perceived by Thai university student. Master Thesis. Tourism Master Program, University of Otago. Dunedin, New Zealand.

[70] Alhemoud, A. M. and E. G. Armstrong. 1996. Image of tourism attractions in Kuwait. Journal of travel Research 34(4), 76-80.

[71] Nassar, M. A., M. M. Mostafa and Y. Reisinger. 2015. Factors influencing travel to Islamic destinations: an empirical analysis of Kuwaiti nationals. International Journal of Culture, Tourism and Hospitality Research 9(1), 36-53.

[72] Gartner, W. C. 1994. Image formation process. Journal of Travel and Tourism Marketing 2(2-3), 191-216.

[73] Baloglu, S. and K. W. McCleary. 1999. A model of destination image formation. Annals of Tourism Research 26(4), 868-897.

[74] PEW Research Centre's Forum on Religion and Public Life. 2009. Mapping the global Muslim population: a report on the size \& distribution of the world's Muslim population. Available at: web.archive.org/ web/20091010050756/http://pewform.org
/newassets/images/reports/Muslimpopulat ion/Muslimpopulation.pdf.

[75] Chandra, G. R. 2014. Halal tourism; a new goldmine for tourism. International Journal of Business Management and Research 4(6), 45-62.

[76] Tribe, J. 2004. 3 Knowing about tourism. In: Goodson, L. and J. Phillimore (Eds). Qualitative Research in Tourism: Ontologies, Epistemologies and Methodologies 14, 46-62.

[77] Babbie, E. 2013. The practice of social research, $13^{\text {th }}$ Ed. International Edition. WCL.

[78] Schreier, M. 2012. Qualitative content analysis in practice. SAGE Publications Inc. Croydon, UK.

[79] Stepchenkova, S., A. P. Kirilenko and A. M. Morrison. 2009. Facilitating content analysis in tourism research. Journal of Travel Research 47(4), 454-469.

[80] Cano, V. and R. Prentice. 1998. Opportunities for endearment to place through electronic 'visiting': homepages and the tourism promotion of Scotland. Tourism Management 19(1), 67-73.

[81] Zhou, Q. and R. DeSantis. 2005. Usability issues in city tourism Web site design: a content analysis. Proceedings. International Professional Communication Conference, 2005. 789-796.

[82] Wenger, A. 2008. Analysis of travel bloggers' characteristics and their communication about Austria as a tourism destination. Journal of Vacation Marketing 14(2), 169-176.

[83] Kim, Y. H., J. Yuan, B. K. Goh and J. M. Antun. 2009. Web marketing in food tourism: A content analysis of web sites in West Texas. Journal of Culinary Science and Technology 7(1), 52-64.

[84] Ministry of Tourism of the Republic of Indonesia. 2016. Dinas Pariwisata. Available at: www.kemenpar.go.id/asp/content.asp? $\mathrm{id}=86$.

[85] Deputy Assistant of Research and Development on Tourism Policy, Ministry of Tourism Republic of Indonesia. 2016. Perkembangan kunjungan wisatawan mancanegara ke Indonesia melalui 19 Pintu masuk utama dan pintu lainnya, 2015 vs 2014. Available at: www.kemenpar.go.id/ asp/detil.asp?c=110\&id=2854.

[86] Ministry of Home Affairs, Republic of Indonesia. (Kementerian Dalam Negeri RI) 
2006. Law of Republic of Indonesia No. about Government of Aceh. Available at: otda.kemendagri.go.id/CMS/Images/Daftar SPM/UU\%20Nomor\%2011\%20Tahun\%2020 06.pdf.

[87] Zambardino, A. 2014. In pictures: New Islamic law in Indonesia. Available at: www.aljazeera.com/indepth/inpictures/201 4/11/pictures-new-islamic-law-indon2014112811847248153.html.

[88] Hampton, M. and J. Hampton. 1998. Is the beach party is over? tourism and the environment in small islands: a case study of Gili Trawangan, Lombok, Indonesia. In: Hitchcock, M., T. V. King and M. Parnwell. Tourism in Southeast Asia: Challenges \& New Directions, 286-308.

[89] Saufi, A. and Rusdan. 2017. Chapter 8 developing halal tourist destination: investigating Lombok's potentials from destination marketing perspective. In: Saufi, A., N. Othman, I. R. Andilolo and A. Lew (Eds). Balancing Development and Sustainability in Tourism Destinations, 6778.

[90] Dahles, H. and K. Bras. 1999. Entrepreneurs in romance tourism in Indonesia. Annals of Tourism Research 26(2), 267-293. 